Мурашко О. В., к.т.н., доцент, докторант, Шевченко В. В., инженер, Бенраді І., аспірант, Абдельхаді М., бакалаврат (Одеська державна академія будівництва і архітектури)

Кубійович М. І., спеціаліст (ПП «Капітель-М»)

\title{
ЗАПОВНЕННЯ ДЕФОРМАЦІЙНИХ ШВІВ МІЖ КАРКАСОМ ТА НЕНЕСУЧИМИ СТІНАМИ ПРИ СТИСКУЮЧОМУ НАВАНТАЖЕННІ
}

Метою даної статті $є$ вивчення поведінки різних видів заповнення антисейсмічних швів між елементами каркаса і ненесучих стін на роботу багатоповерхових будівель з залізобетонним безрігельним каркасом при сейсмічних впливах. Вплив заповнення було проаналізовано на найбільш широко застосовуваних в Україні трьох видах заповнення: мінеральної вати, пінополістирола і вілатерм. Об'єктами дослідження $є$ три газобетонні призми і одна призма з важкого бетону з матеріалом заповнення швів при стискаючих навантаженнях. Переміщення від вертикальних навантажень на випробуваних зразках - ключові параметри для визначення впливу утеплювача на поведінку будівель зі стіновим заповненням під час землетрусів. Другим параметром, який також був проаналізований, є зміна геометричної форми і повного руйнування заповнювача шва (утеплювача).

Ключові слова: сейсмостійкість, несуча здатність, заповнення деформаційних швів, малоциклове навантаження.

Вступ. В існуючих державних будівельних нормах, присутні значні суперечності, в підході до урахування ненесучого стінового заповнення. Нормативний документ (ДБН В.1.1-12 2006) [1] вимагає виконання «зазорів величиною 20 мм. для забезпечення самостійної роботи каркаса без урахування стінового заповнення. Шви заповнюються пружним еластичним матеріалом». При цьому в новій редакції ДБН В.1.1-12-2014, [2] ця вимога залишилась без змін, але з'явилися вимоги щодо обмеження перекосів з урахуванням нелінійної роботи. Але для типового поверху, ми бачимо, що каркас нормально працює і при 50 мм переміщеннях поверху. Таким чином необхідний 20 мм зазор не виконує своєї функції. Для визначення ступеня впливу несучих стінового заповнення залізобетонного каркаса була розроблена програма експерименту, який включає в себе два етапи. 
Перший етап визначення ступеня впливу заповнення деформаційних швів. Другий етап випробування фрагментів стін 3 урахуванням впливу заповнення деформаційних швів. Дане дослідження присвячено першому етапу.

Мета роботи - виявити ступінь впливу заповнення деформаційних з найбільш поширених матеріалів: мінеральної вати, пінополістиролу і вілатерма між ненесучими стінами з газобетону і елементами каркаса.

Матеріали та методи. Для визначення переміщення і визначення несучої здатності передбачено 3 зразки призм з газобетону $\mathrm{i}$ 1 бетонної призми. Для вимірювань деформацій утеплювача, застосовувалися індикатори годинникового типу 3 ціною поділки 0,01 мм і з базою 30 мм, [3]. Датчики наклеювалися на дві протилежні грані призми.

Реалізацію випробовування було виконано наступним чином:

- поклеювання п'яти на призми для індикаторів, що визначають переміщення (ріс. 1, a);

- установка індикаторів (рис. 1, б).

- Підготовка зразків заповнення швів:

- Мінеральна вата (100×100×20 мм) (рис. 1, в);

- Пінополістірол (100×100×20 мм) (рис. 1, г);

- Вілатерм (l = 20 мм) (рис. 1, д).

Результати. Результати випробувань наведено у вигляді таблиць, діаграм залежності переміщення від завантаження заповнювача і діаграм малоциклових навантаженнь дослідних зразків.

\begin{tabular}{|c|c|c|c|}
\hline \multicolumn{3}{|c|}{ Мінеральна вата } & \multirow{2}{*}{$\begin{array}{c}\text { Середнє } \\
\text { значення, } \\
\text { мм }\end{array}$} \\
\hline $\begin{array}{c}\text { Навантаження, } \\
\text { кH }\end{array}$ & $\begin{array}{c}\text { Показання, мм } \\
\text { Індикатор } 1\end{array}$ & $\begin{array}{c}\text { Показання, мм } \\
\text { Індикатор } 2\end{array}$ & \\
\hline Ст $1(2 \kappa \mathrm{H})$ & 26 & 24,13 & 25,06 \\
\hline Ст 2 (4кH) & 26,24 & 24,34 & 25,29 \\
\hline Ст 3 (6кH) & 26,62 & 24,72 & 25,67 \\
\hline Ст 4 (8кH) & 26,93 & 25,02 & 25,97 \\
\hline Ст 5(10кН) & 27,11 & 25,20 & 26,15 \\
\hline Ст 6 (12кH) & 27,27 & 25,37 & 26,32 \\
\hline Ст 7 (14кH) & 27,41 & 25,52 & 26,46 \\
\hline Ст 8 (16кН) & 27,5 & 25,63 & 26,56 \\
\hline Ст 9 (18кH) & 27,6 & 25,75 & 26,67 \\
\hline
\end{tabular}




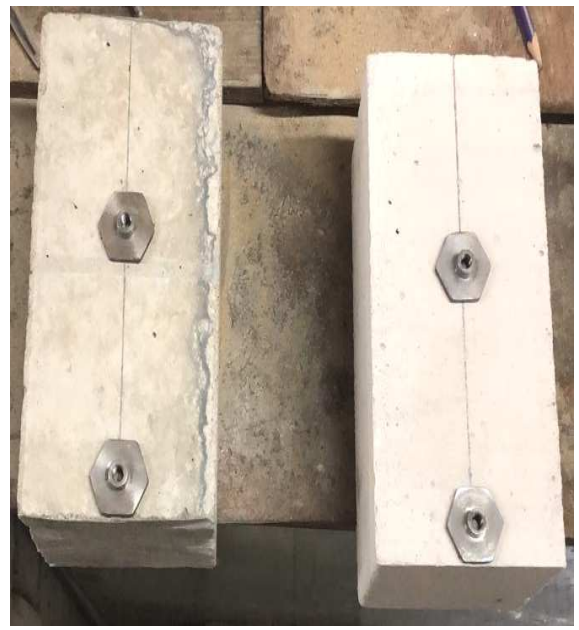

Puc. 1, a

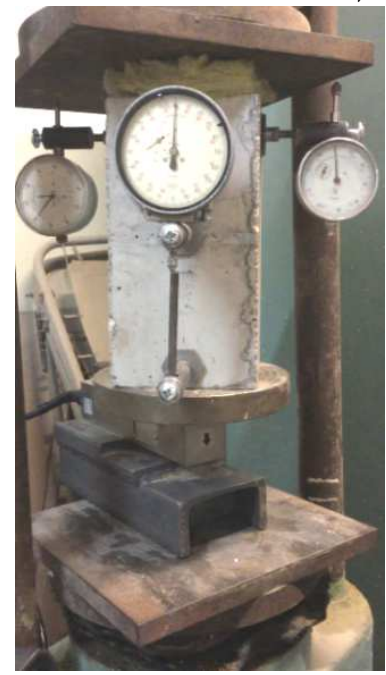

Рис. 1, в

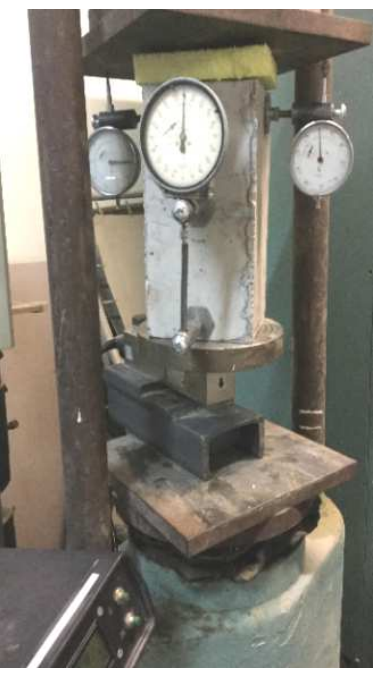

Pис. 1, r

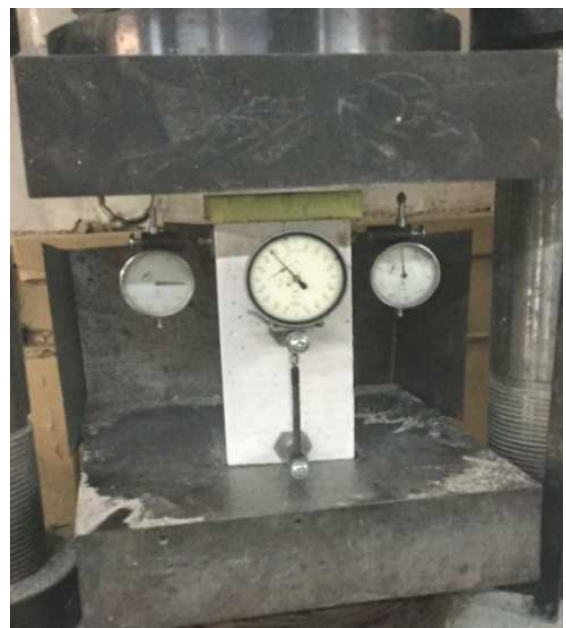

Рис. 1, б

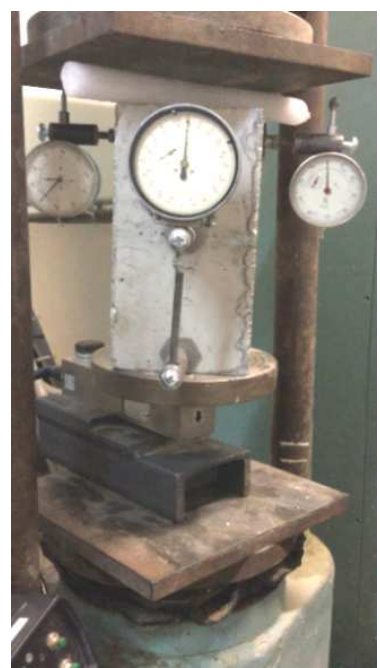

Рис. 1, д

\section{Мінеральна вата}

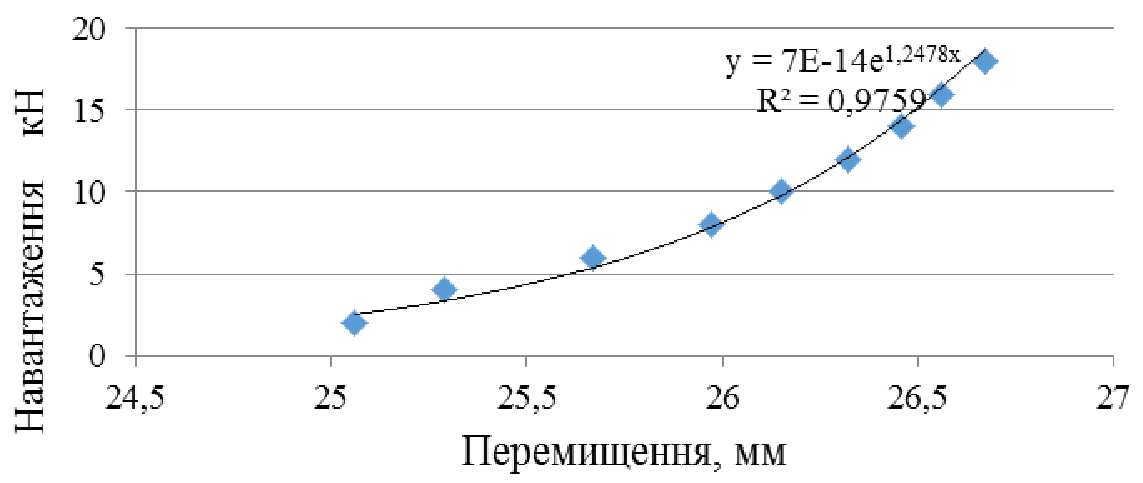

Рис. 2. Діаграма залежності переміщення від навантаження мінеральної вати 
Виходячи з даної діаграми видно, що при поступовому навантаження мінеральна вата витримує 1,8 тонни, після чого при візуальному огляді даний зразок був повністю зруйнований і не повернув своєї первісної форми.

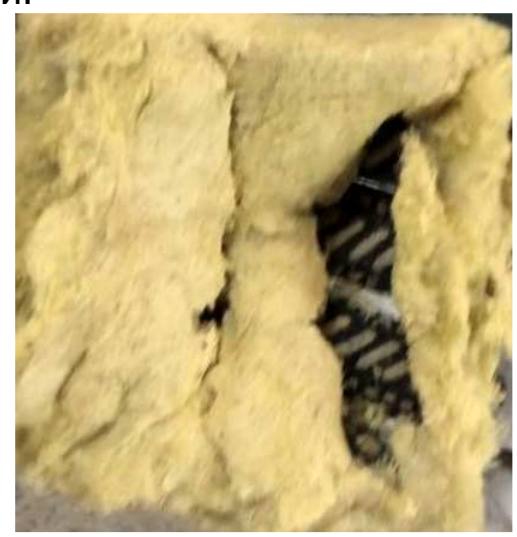

Рис. 3. Зразок після поступового навантаження до критичного (1,8 тонни)

Показання індикаторі переміщення в при мало цикловому навантаженні приведені в табличній формі (табл. 2).

Таблиця 2

\begin{tabular}{|c|c|c|}
\hline № циклу & Поч. показання, мм & Кін. показання, мм \\
\hline 1 цикл & 0 & 26,67 \\
\hline 2 цикл & 21,20 & 26,67 \\
\hline 3 цикл & 23,47 & 26,67 \\
\hline 4 цикл & 23,9 & 26,67 \\
\hline 5 цикл & 25,6 & 26,67 \\
\hline
\end{tabular}

\section{Мінеральна вата}

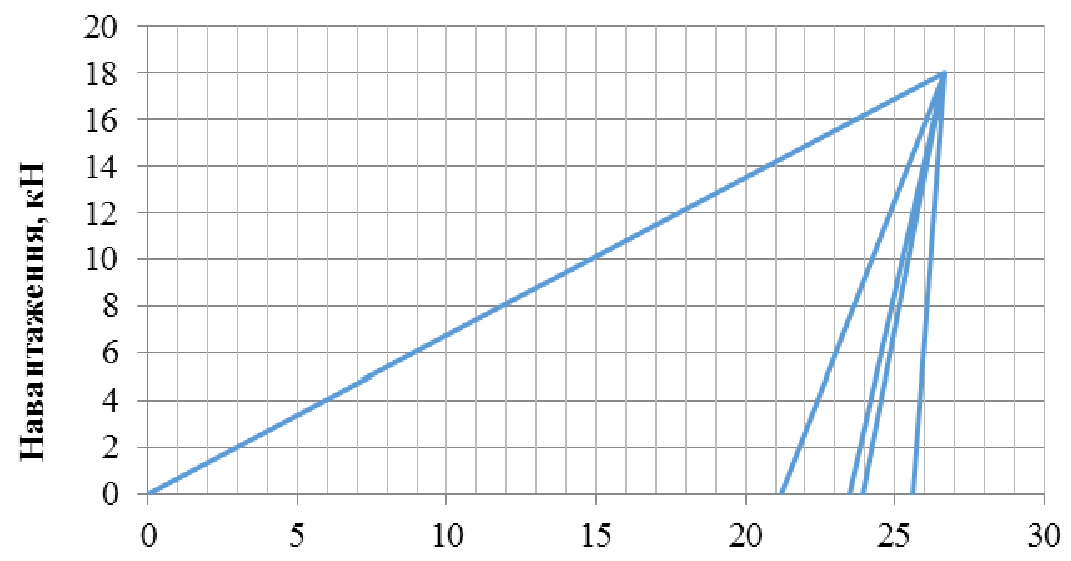

Переміщення, мм

Рис . 4. Діаграма напружено деформованого стану при мало цикловому навантаженні мінеральної вати 


\section{Мінеральна вата}

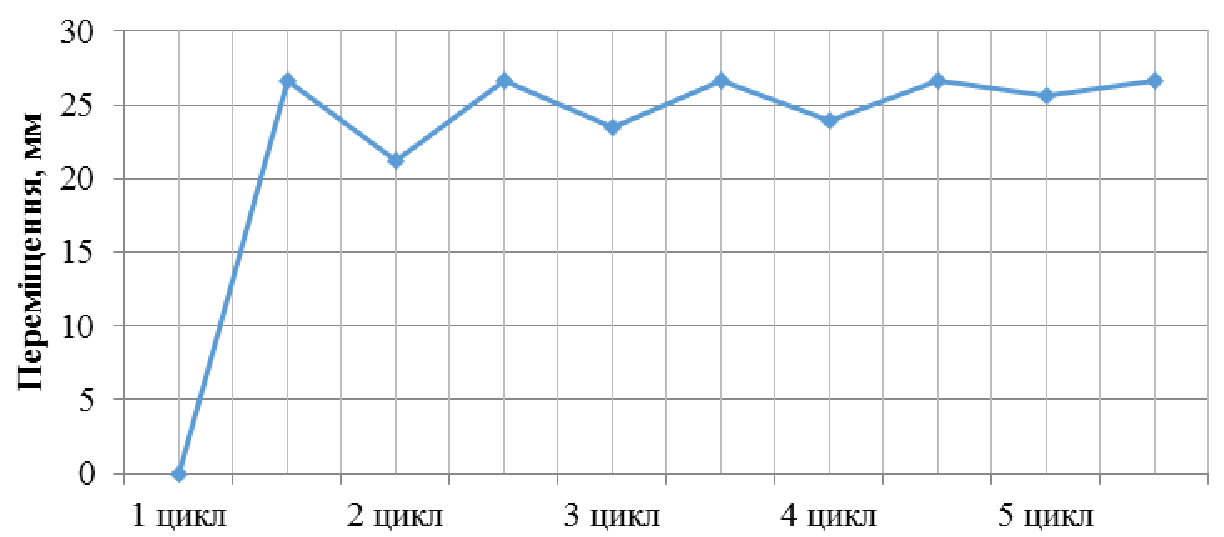

№ Цикла

Рис. 5. Діаграма зміни деформацій в залежності від циклу при мало цикловому завантаженню мінеральної вати (верхні точки - відповідають навантаженню 1,8 тонни, нижні - повна розгрузка)

Таблиця 3

\begin{tabular}{|c|c|c|c|}
\hline \multicolumn{3}{|c|}{ Пінополістирол } & \multirow{3}{*}{$\begin{array}{c}\text { Среднє зна- } \\
\text { чення, мм }\end{array}$} \\
\hline \multirow{2}{*}{ Навантаження } & Показання, мм & Показання, мм & \\
\hline & Індикатор 1 & Індикатор 2 & \\
\hline \multirow{2}{*}{ Ст 1 (2кН) } & Поч. 3,47 & Поч. 3,87 & 3,67 \\
\hline & Кін. 9,85 & Кін. 10,07 & 9,96 \\
\hline \multirow{2}{*}{ Ст 2 (4кH) } & Поч. 14,67 & Поч. 14,97 & 14,82 \\
\hline & Кін. 15,22 & Кін. 15,56 & 15,39 \\
\hline \multirow{2}{*}{ СТ 3 (6кH) } & Поч. 15,97 & Поч. 16,17 & 16,07 \\
\hline & Кін. 16,26 & Кін. 16,87 & 16,565 \\
\hline \multirow{2}{*}{ СТ 4 (8кH) } & Поч. 17,42 & Поч. 17,77 & 17,595 \\
\hline & Кін. 18,03 & Кін. 18,39 & 18,21 \\
\hline \multirow{2}{*}{ Ст 5(10кН) } & Поч. 18,42 & Поч. 18,57 & 18,495 \\
\hline & Кін. 18,62 & Кін. 18,87 & 18,745 \\
\hline \multirow{2}{*}{ Ст 6 (12кH) } & Поч. 18,72 & Поч. 19,07 & 18,895 \\
\hline & Кін. 18,92 & Кін. 19,27 & 19,095 \\
\hline \multirow{2}{*}{ Ст 7 (14кH) } & Поч. 19,07 & Поч. 19,37 & 19,22 \\
\hline & Кін. 19,31 & Кін. 19,57 & 19,44 \\
\hline Ст 8 (16кH) & 19,37 & 19,67 & 19,52 \\
\hline Ст 9 (18кH) & 19,54 & 19,86 & 19,7 \\
\hline Ст $10(20 \mathrm{kH})$ & 19,8 & 20,09 & 19,945 \\
\hline СТ 11 (22кH) & 19,92 & 20,23 & 20,075 \\
\hline СТ $12(24 \mathrm{KH})$ & 20,08 & 20,37 & 20,225 \\
\hline СТ $13(26 \mathrm{kH})$ & 20,17 & 20,47 & 20,32 \\
\hline СТ $14(28 \mathrm{kH})$ & 20,27 & 20,57 & 20,42 \\
\hline Ст 15 (30кH) & 20,32 & 20,62 & 20,47 \\
\hline
\end{tabular}




\section{Пінополістирол}

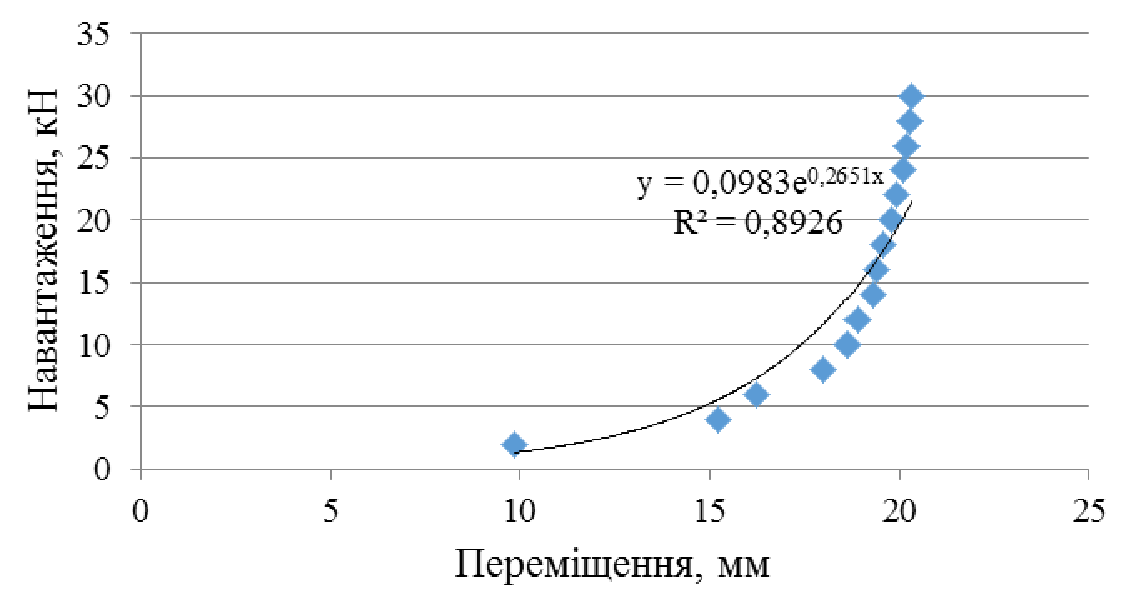

Рис. 6. Діаграма залежності переміщення від завантаження пінополістиролу

Виходячи с даної діаграми бачимо, що при поступовому навантаженню пінополістирол витримує 3 тонни, після чого при візуальному огляді даний зразок повернув приблизно 60\% своєї первісної форми після повного стиснення.

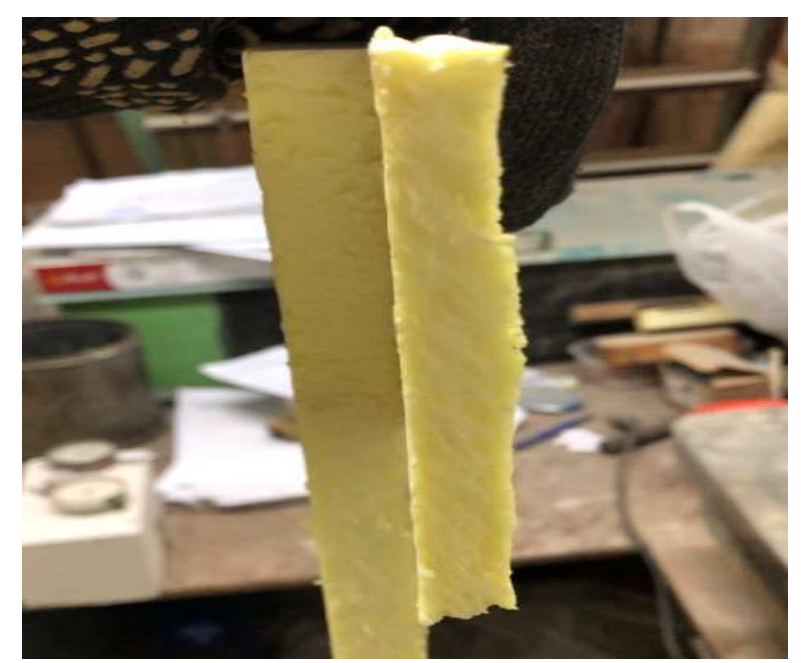

Рис. 7. Зразок до та після поступового навантаження до критичного (3 тонни)

Показання індикаторів переміщення при мало цикловому навантаженні пінополістиролу приведені в табличній формі (табл. 4). 
Таблиця 4

\begin{tabular}{|l|l|l|}
\hline № циклу & Поч. показання, мм & Кін. показання, мм \\
\hline 1 цикл & 0 & 23,32 \\
\hline 2 цикл & 13,62 & 20,32 \\
\hline 3 цикл & 18,84 & 23,32 \\
\hline 4 цикл & 13,95 & 23,32 \\
\hline 5 цикл & 13,97 & 23,32 \\
\hline
\end{tabular}

\section{Пінополистирол}

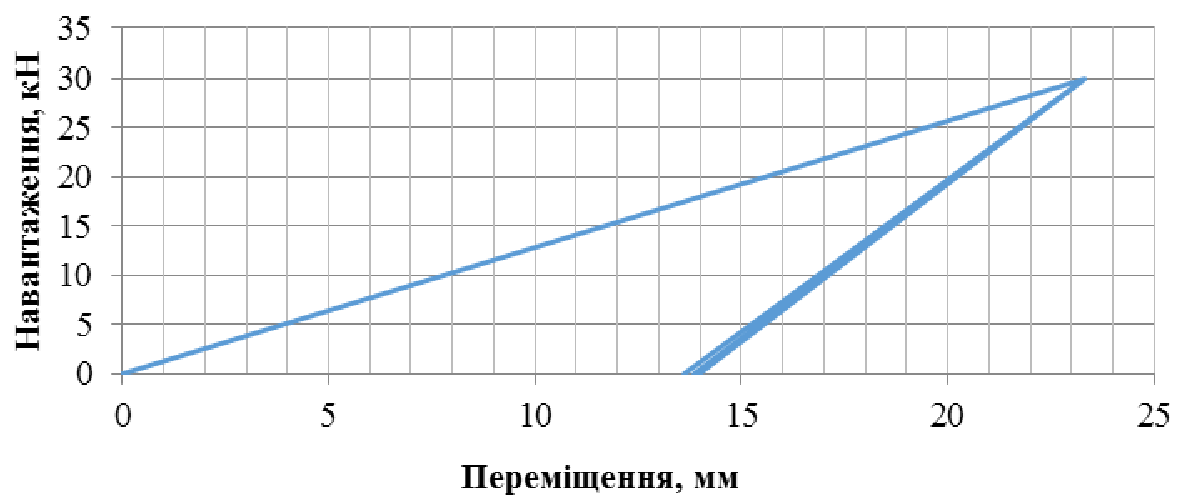

Рис. 8. Діаграма напружено деформованого стану при мало цикловому навантаженні пінополістиролу

\section{Пінополистирол}

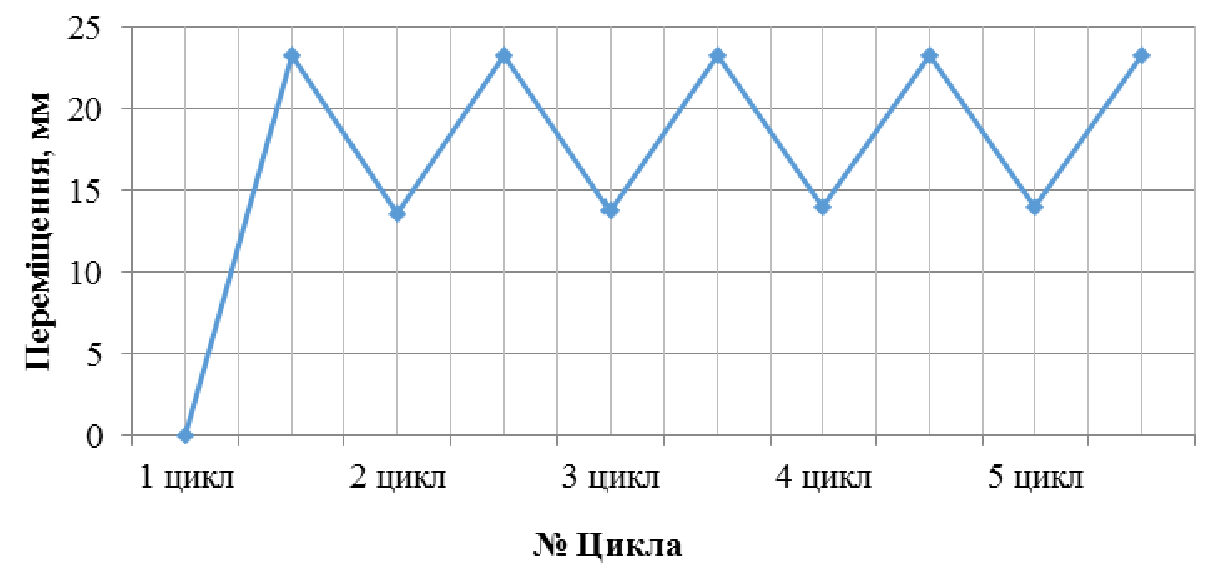

Рис. 9. Діаграма зміни деформацій в залежності від циклу при мало цикловому завантаженню пінополістиролу (верхні точки - відповідають навантаженню 3 тонни, нижні - повна розгрузка) 
Таблиця 5

\begin{tabular}{|c|c|c|c|}
\hline \multicolumn{3}{|c|}{ Вілатерм } & \multirow{3}{*}{$\begin{array}{c}\text { Среднє зна- } \\
\text { чення, мм }\end{array}$} \\
\hline \multirow{2}{*}{ Навантаження } & Показання, мм & Показання, мм & \\
\hline & Індикатор 1 & Індикатор 2 & \\
\hline Ст 1 (2кH) & 20,14 & 19,14 & 19,64 \\
\hline Ст 2 (4kH) & 20,52 & 19,35 & 19,935 \\
\hline Ст $3(6 \mathrm{kH})$ & 21,22 & 19,74 & 20,48 \\
\hline Ст 4 (8кH) & 21,55 & 19,93 & 20,74 \\
\hline Ст $5(10 \mathrm{kH})$ & 21,78 & 20,04 & 20,91 \\
\hline Ст 6 (12кH) & 21,96 & 20,15 & 21,055 \\
\hline Ст 7 (14kH) & 22,05 & 20,19 & 21,12 \\
\hline
\end{tabular}

Вілатерм

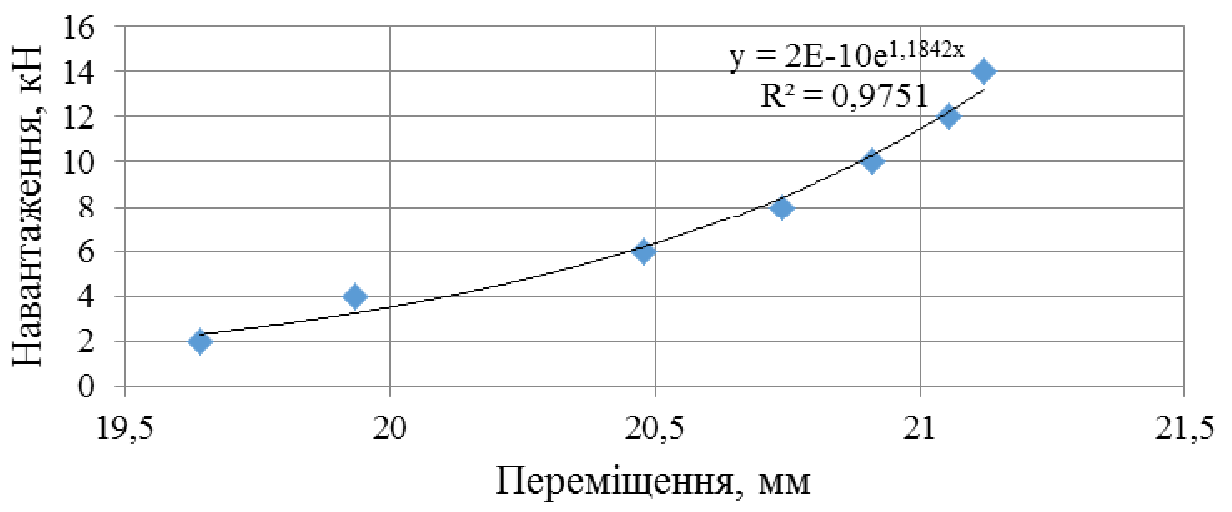

Рис. 10. Діаграма залежності переміщення від завантаження вілатерму

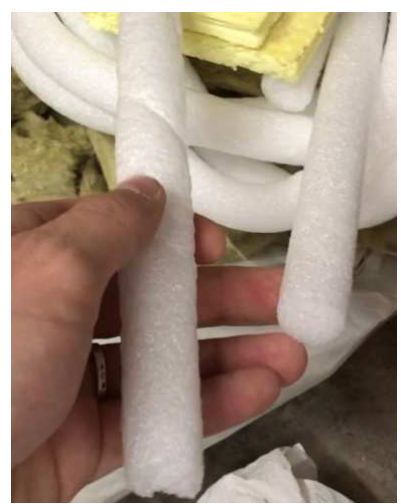

Рис. 11. Зразок після поступового навантаження до критичного (1,4 тонни)

Показання індикаторів переміщення при мало цикловому навантаженні приведені в табличній формі (табл. 6). 
Таблиця 6

\begin{tabular}{|c|c|c|}
\hline № циклу & Поч. показання, мм & Кін. показання, мм \\
\hline 1 цикл & 0 & 21,12 \\
\hline 2 цикл & 10,3 & 21,12 \\
\hline з цикл & 10,47 & 21,12 \\
\hline 4 цикл & 10,62 & 21,12 \\
\hline 5 цикл & 10,75 & 21,12 \\
\hline
\end{tabular}

\section{Вілатерм}

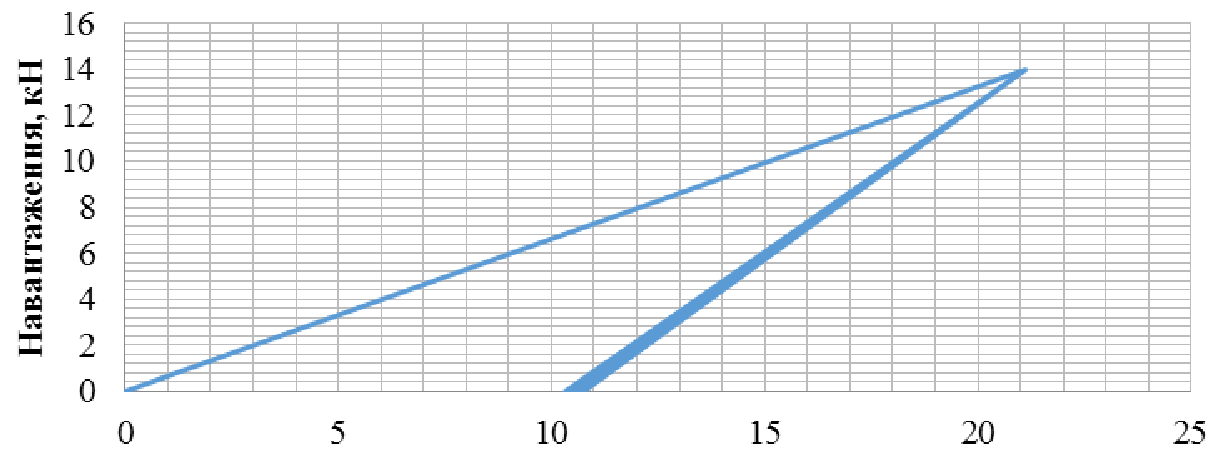

Переміщення, мм

Рис. 12. Діаграма напружено деформованого стану при мало цикловому навантаженні вілатерму

\section{Вілатерм}

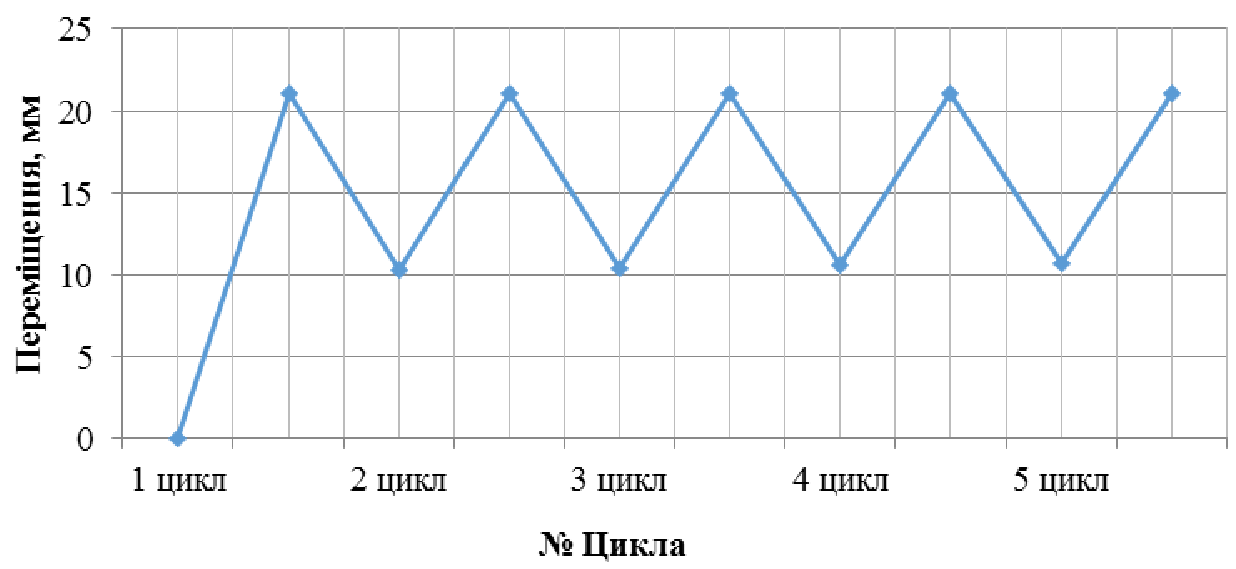

Рис. 13. Діаграма зміни деформацій в залежності від циклу при мало цикловому завантаженню вілатерму (верхні точки - відповідають навантаженню 1,4 тонни, нижні - повна розгрузка) 


\section{Висновки}

За результатами статичного і малоциклового навантаження мінеральної вати, пінополістиролу і вилатерма на бетонних і газобетонних призмах, можна зробити висновок:

1. Усі три види заповнення продовжують брати участь в роботі стінового заповнення аж до повного руйнування газобетонной призми, що імітує роботу стіни.

2. Мінеральна вата після 2-го циклу зруйнувалася, і не повернула свої попередні форми, а також не зберігає свої пружно пластичні властивості.

3. Пінополістирол і вілатерм після поступового і малоциклового навантаження зберегли свої пружно-пластичні властивості, що можна побачити виходячи з наведених графіків і візуального огляду матеріалу після проведення експериментальних випробувань.

4. 3 урахуванням отриманих результатів необхідно підготувати і провести другий етап лабораторних досліджень.

1. ДБН В. 1.1-12:2006. Строительство в сейсмических районах Украины. Министерство строительства, архитектуры и жилищно-коммунального хозяйства Украины. Киев, 2006. 84 с. 2. ДБН В.1.1-12:2014. Будівництво у сейсмічних районах України. [Чинні від 2014-10-01]. К. : Мінрегіон України, 2014. VI, 84, 110 с. (Будівельні норми України). 3. ДСТУ ГОСТ 577:2009. Индикаторы часового типа с ценой деления 0,01 мм. Технические условия. [Действует с 2009-02-01]. М., 2002. 12 с. 4. ГОСТ 10180-90 (СТ СЭВ 3978-83). Бетоны. Методы определения прочности по контрольным образцам. М. : Изд-во стандартов, 1989. 5. ДСТУ Б В.2.6-7-95 (ГОСТ 8829-94). Конструкції будинків і споруд. Вироби будівельні бетонні та залізобетонні збірні. Методи випробувань навантажуванням. Правила оцінки міцності, жорсткості та тріщиностійкості. [Чинний від 1996-04-01]. К. : Державний комітет України у справах містобудування і архітектури, 1997. IV, 30 с. (Національний стандарт України). 6. EN 1998-1, Eurocode 8: Design of structures for earthquake resistance Part 1: General rules, seismic actions and rules for buildings. 7. V. Dorofeev, K. Yegupov, A. Murashko, O. Adamov. A new approach to buildings seismic resistance assessment in Ukraine. Proceedings of the 2-nd European Conference on Earthquake Engineering and Seismology, August 24-29, 2014, Istambul, Turkey pp. 138-143. 8. Shaochun Ma, Nan Jiang Seismic Experimental Study on New-Type Composite Exterior Wallboard with Integrated Structural Function and Insulation. 9. ANDREEA-TEREZIA MIRCEA, RUXANDRA CRUTESCU Research Contributions to the Seismic Performance of ICF Technology Wall Systems. 10. Vincenzo Manfredi, Angelo Masi. Seismic Strengthening and Energy Efficiency: Towards an Integrated Approach for the Rehabilitation of Existing RC Buildings. 


\section{REFERENCES:}

1. DBN V. 1.1-12:2006. Stroitelstvo $v$ seismicheskikh raionakh Ukrainy. Ministerstvo stroitelstva, arkhitektury i zhilishchno-kommunalnoho khoziaistva Ukraini. Kyev, 2006. 84 s. 2. DBN V.1.1-12:2014. Budivnytstvo u seismichnykh raionakh Ukrainy. [Chynni vid 2014-10-01]. K. : Minrehion Ukrainy, 2014. VI, 84, 110 s. (Budivelni normy Ukrainy). 3. DSTU HOST 577:2009. Indikatory chasovoho tipa s tsenoi deleniia 0,01 mm. Tekhnicheskie usloviia. [Deistvuet s 2009-02-01]. M., 2002. 12 s. 4. HOST 10180-90 (ST SЭV 3978-83). Betony. Metody opredeleniia prochnosti po kontrolnym obraztsam. M. : Izd-vo standartov, 1989. 5. DSTU B V.2.6-7-95 (HOST 8829-94). Konstruktsii budynkiv i sporud. Vyroby budivelni betonni ta zalizobetonni zbirni. Metody vyprobuvan navantazhuvanniam. Pravyla otsinky mitsnosti, zhorstkosti ta trishchynostiikosti. [Chynnyi vid 1996-04-01]. K. : Derzhavnyi komitet Ukrainy u spravakh mistobuduvannia i arkhitektury, 1997. IV, 30 c. (Natsionalnyi standart Ukrainy). 6. EN 1998-1, Eurocode 8: Design of structures for earthquake resistance Part 1: General rules, seismic actions and rules for buildings. 7. V. Dorofeev, K. Yegupov, A. Murashko, O. Adamov. A new approach to buildings seismic resistance assessment in Ukraine. Proceedings of the 2-nd European Conference on Earthquake Engineering and Seismology, August 24-29, 2014, Istambul, Turkey pp. 138-143. 8. Shaochun $\mathrm{Ma}$, Nan Jiang Seismic Experimental Study on New-Type Composite Exterior Wallboard with Integrated Structural Function and Insulation. 9. ANDREEATEREZIA MIRCEA, RUXANDRA CRUTESCU Research Contributions to the Seismic Performance of ICF Technology Wall Systems. 10. Vincenzo Manfredi, Angelo Masi. Seismic Strengthening and Energy Efficiency: Towards an Integrated Approach for the Rehabilitation of Existing RC Buildings.

Murashko 0. V., Candidate of Engineering (Ph.D.), Associate Professor, Shevchenko V. V., Engineer at the Department of PSK, Benradi I., Post-graduate Student, Abdelhadi M., Bachelor's Degree (Odessa State Academy of Civil Engineering and Architecture), Kubiiovych M. I., Specialist (PE “Kapitel-M")

\section{FILLING OF THE DEFORMATION JOINTS BETWEEN THE FRAMEWORK AND THE NON-CARRYING WALLS WITH COMPRESSIVE LOAD}

The purpose of this article is to study the behavior of various types of anti-seismic joints fillers between frame elements and non-structural wall infill on the behavior of multi-storey buildings with a reinforced concrete flat-slab frame under seismic effects. Reinforced concrete 
buildings are predominant type of construction in developing countries like Ukraine. Seismic performance of these buildings, is not predictable through techniques based on secondary factors such as short column, irregularities in plan and elevation, soft and weak stories, strong beam-weak column can causes serious damages. And also all this factors can be caused by irregular non-structural wall infill. And if much attention is paid to the study of non-structural wall infill effect, then the issue of the expansion joint between the frame and the filling remains unexplored. Also this problem is caused by contradictions in DBN B.1.1-12-2014, which limits the gap between the frame and non-structural wall by $20 \mathrm{~mm}$. But for a typical floor, we see that the frame works normally and at $50 \mathrm{~mm}$ (according to pushover analysis) displacements of the floor. Thus, the required $20 \mathrm{~mm}$ gap does not perform its function. To determine the degree of impact of the non-bearing walls on the reinforced concrete frame, an experimental program was developed that includes two steps. The first stage is to determine the degree of impact of filling the joints. The second stage is testing the wall fragments, taking into account the effect of filling the deformation joints. This study focuses on the first stage. In this paper the influence of the joint filling was analyzed using the three most widely used types in Ukraine: mineral wool, polystyrene foam and vilatherm. The objects of study are three aerated concrete prisms and one prism made of heavy concrete with filling material. Displacements from vertical loads on test samples are key parameters for determining the effect of joint filler on the behavior of buildings during earthquakes. The second parameter, which was also analyzed, the change of geometric form and complete destruction of the joint filler. This study was undertaken to develop the future Ukrainian Rapid visual screening assessment procedure that takes into account the influence of anti-seismic joints fillers. Keywords: seismic resistance, load bearing capacity, deformation joint filler, low cycle load.

Мурашко А. В., к.т.н., доцент, Шевченко В. В., инженер кафедры ПСК, Бенради И., аспирант, Абдельхади М., бакалавриат (Одесская государственная академия строительства и архитектуры), Кубийович Н. И., специалист (000 «Капитель-М») 


\section{ЗАПОЛНЕНИЕ ДЕФОРМАЦИОННЫХ ШВОВ МЕЖДУ КАРКАСОМ И НЕНЕСУЩИМИ СТЕНАМИ ПРИ СЖИМАЮЩИХ ВОЗДЕЙСТВИЯХ}

Целью данной статьи является изучение поведения различных видов заполнения антисейсмических швов между элементами каркаса и несущих стен на работу многоэтажных зданий с железобетонным безригельным каркасом при сейсмических воздействиях. Влияние заполнения было проанализировано на самых широко применяемых в Украине трех видах заполнения: минеральной ваты, пенополистирола и вилатерма. Объектами исследования являются три газобетонные призмы и одна призма из тяжелого бетона с материалом заполнения швов при сжимающих нагрузках. Перемещение от вертикальных нагрузок на испытываемых образцах ключевые параметры для определения влияния утеплителя на поведение зданий со стеновым заполнением во время землетрясений. Вторым параметром, который также был проанализирован, является изменение геометрической формы и полного разрушения заполнителя шва (утеплителя).

Ключевые слова: сейсмостойкость, несущая способность, заполнение деформационных швов, малоцикловое нагружение. 